\author{
DEVELOPMENT AND EVALUATION OF STABLE ISOTOPE AND \\ FLUORESCENT LABELING AND DETECTION METHODOLOGIES FOR \\ TRACKING INJECTED BACTERIA DURING IN SITU BIOREMEDIATION
}

FINAL TECHNICAL REPORT

For Period July 28, 1998 to August 15, 2003

Tullis C. Onstott

PRINCETON UNIVERSITY

Princeton, NJ 08544

November 30, 2003

Prepared for

THE UNITED STATES DEPARTMENT OF ENERGY

OFFICE OF SCIENCE

AWARD NO. DE-FG02-98ER62712 


\section{DISCLAIMER}

This report was prepared as an account of work sponsored by an agency of the United States Government. Neither the United States nor any agency thereof, nor any of their employees, makes any warranty, express or implied, or assumes any legal liability or responsibility of the accuracy, completeness that its use would not infringe privately owned rights. Reference herein to any specific commercial product, process, or service by trade name, trademark, manufacturer, or otherwise does not necessarily constitute or imply its endorsement, recommendation, or favoring by the United States Government or any agency thereof. The views and opinions of authors expressed herein do not necessarily state or reflect those of the United States Government or any agency thereof.

Available for sale to the public from

U.S. Department of Commerce

National Technical Information Service

5285 Port Royal Rd.

Springfield, VA 22161

T: 800-553-6847

F: 703-605-6900

orders@ntis.fedworld.gov

Order online: http://www.ntis.gov/ordering.htm 


\title{
Development and evaluation of stable isotope and fluorescent labeling and detection methodologies for tracking injected bacteria during in situ bioremediation.
}

\begin{abstract}
The goal of this research project was to develop new methods to label bacterial cells so that they could be tracked and enumerated as they move in the subsurface after they are introduced into the groundwater (i.e., during bioaugmentation). Labeling methods based on stable isotopes of carbon $\left({ }^{13} \mathrm{C}\right)$ and vital fluorescent stains were developed. Both approaches proved successful with regards to the ability to effectively label bacterial cells. Several methods for enumeration of fluorescently-labeled cells were developed and validated, including near-real time microplate spectrofluorometry that could be performed in the field. However, the development of a novel enumeration method for the ${ }^{13} \mathrm{C}$-enriched cells, chemical reaction interface/mass spectrometry (CRIMS), was not successful due to difficulties with the proposed instrumentation. Both labeling methodologies were successfully evaluated and validated during laboratory- and field-scale bacterial transport experiments. The methods developed during this research should be useful for future bacterial transport work as well as other microbial ecology research in a variety of environments.
\end{abstract}

\section{SUMMARY OF RESULTS}

The procedures and results of this research project have been detailed in manuscripts and meeting presentations over the duration of the project. The core of the methods that was developed during this research project is presented in an Applied and Environmental Microbiology article published in October 2000, which is available for download at http://aem.asm.org/cgi/reprint/66/10/4486.pdf. The reader is directed to the PUBLICATIONS AND PRESENTATIONS section of this report for specific details regarding the other various aspects of this project.

A summary of the major results that were obtained during this project is as follows:

1) A yellow-green stain, CFDA/SE (5-(and-6-)-carboxyfluorescein diacetate, succinimidyl ester) was found to be able to label bacterial cells with no undesirable effects on viability or transport. Stained cells remained 
fluorescent for at least five months. A red-orange stain, TAMRA/SE (5-(and6)-carboxytetramethylrhodamine, succinimidyl ester) was found that could also efficiently label cells for an extended duration.

2) A sequential culturing method was developed which resulted in cells that were highly isotopically enriched for ${ }^{13} \mathrm{C}$. These cells were detectable using both isotope ratio mass spectrometry and high performance liquid chromatography/electrospray/mass spectrometry.

3) Detection and enumeration methods for CFDA/SE-stained and TAMRA/SEstained cells were developed, including epifluorescence microscopy and high throughput microplate spectrofluorometry. Two additional detection methods, flow cytometry and ferrographic capture, were found to be effective for enumerating CFDA/SE-stained cells, but flow cytometry was not effective for enumerating TAMRA/SE-stained cells with the standard configuration of the flow cytometer.

4) A reproducible protocol for staining cells with CFDA/SE and TAMRA/SE has been developed, and successfully scaled-up to allow staining of $10 \mathrm{~L}$ of bacterial cells.

5) The microplate spectrofluorometry method has been optimized for detection of both CFDA/SE-stained and TAMRA/SE-stained in the same sample under both laboratory and field conditions. Analysis time for 24 samples (4 replicates per sample) was approximately two minutes.

6) The use of cells enriched in stable carbon isotope $\left({ }^{13} \mathrm{C}\right)$ was successfully evaluated during a field injection at the NABIR bacterial transport field site in Oyster, VA.

7) The use of the fluorescent staining and enumeration procedures were successfully evaluated during three field injections at the NABIR Bacterial Transport field site in Oyster, VA.

8) Multiple manuscripts related to this research have been published and/or submitted for publication. Multiple posters and platform sessions at national and international scientific meetings related to this research have been presented (see below). 


\section{PUBLICATIONS AND PRESENTATIONS}

\section{Peer Reviewed Journal Articles}

Fuller M. E., Dong H., Mailloux B. J., Onstott T. C., and DeFlaun M. F. (2000) Examining bacterial transport in intact cores from Oyster, Virginia: Effect of sedimentary facies type on bacterial breakthrough and retention. Water Resources Research 36: 2417-2431.

doi:10.1029/2000WR900075, 2000.

Fuller M. E., Hall J. A., Mailloux B. J., Streger S. H., Zhang P., Vainberg S. N., Johnson W. P., Onstott T. C., and DeFlaun M. F. Application of a vital fluorescent staining method for simultaneous, near-real-time concentration monitoring of two bacterial strains in an Atlantic Coastal Plain aquifer in Oyster, Virginia. Applied and Environmental Microbiology (Accepted/in press).

Fuller M. E., Mailloux B. J., Zhang P., Streger S. H., Hall J. A., Vainberg S. N., Beavis A. J., Johnson W. P., Onstott T. C., and DeFlaun M. F. (2001) Field-scale evaluation of CFDA/SE staining coupled with multiple detection methods for assessing the transport of bacteria in situ. FEMS Microbiology Ecology 37: 55-66.

http://dx.doi.org/10.1016/S0168-6496(01)00143-X.

Fuller M. E., Streger S. H., Rothmel R. K., Mailloux B. J., Onstott T. C., Fredrickson J. K., Balkwill D. L., and DeFlaun M. F. (2000) Development of a vital fluorescent staining method for monitoring bacterial transport in subsurface environments. Applied and Environmental Microbiology 66: 4486-4496.

http://aem.asm.org/cgi/reprint/66/10/4486.pdf.

Balkwill D., Chen J., Dobbs F., Dong H., Fredrickson J., Fuller M., Green M., Ginn T., Griffin T., Holben W., Hubbard S., Johnson W., Long P., Mailloux B., Majer E., McInerney M., Murray C., Onstott T., Phelps T., Scheibe T., Swift D., White D., and 
Wobber F. (2001) Breakthroughs in field-scale bacterial transport. EOS Transactions, American Geophysical Union 82: 417,423-425.

DeFlaun M. F., Fuller M. E., Zhang P., Johnson W. P., Mailloux B. J., Holben W. E., Kovacik W. P., Balkwill D. L., and Onstott T. C. (2001) Comparison of methods for monitoring bacterial transport in the subsurface. Journal of Microbiological Methods 47: 219-231.

http://dx.doi.org/10.1016/S0167-7012(01)00307-4.

Dong H., Onstott T. C., DeFlaun M. F., Fuller M. E., Streger S. H., Rothmel R. K., and Mailloux B. J. (2002) Relative dominance of physical versus chemical effects on the transport of adhesion-deficient bacteria in intact cores from South Oyster, Virginia. Environmental Science and Technology 36: 891-900.

http://dx.doi.org/10.1021/es010144t.

Dong H., Rothmel R. K., Onstott T. C., Fuller M. E., DeFlaun M. F., Dunlap R., and Fletcher M. (2002) Simultaneous transport of two bacterial strains in intact cores from Oyster, Virginia: Biological effects and numerical modeling. Applied and Environmental Microbiology 68: 2120-2132.

http://aem.asm.org/cgi/reprint/68/5/2120.pdf.

Dong H., Scheibe T. D., Johnson W. P., Monkman C. M., and Fuller M. E. Direct determination of change of bacterial collision efficiency with transport distance in field scale bacterial transport experiments. Journal of Contaminant Hydrology (Submitted):

Hall J. A., Mailloux B. J., Long K., Onstott T. C., Fuller M., and DeFlaun M. Physical versus chemical effects on bacterial transport as determined during in situ short-core pulse experiments. Water Resources Research (In preparation): 
Johnson W. P., Zhang P., Fuller M. E., Scheibe T., Mailloux B. J., Onstott T. C., DeFlaun M. F., Hubbard S. S., Radtke J., Kovacik W. P., and Holben W. (2001) Ferrographic tracking of bacterial transport in the field at Oyster, VA. Environmental Science \& Technology 35: 182-191.

http://dx.doi.org/10.1021/es001170e.

Johnson W. P., Zhang P., Gardner P. M., Fuller M. E., and DeFlaun M. F. (2001) Evidence for detachment of indigenous bacteria from aquifer sediment in response to arrival of injected bacteria. Applied and Environmental Microbiology 67: 4908-4913. http://aem.asm.org/cgi/reprint/67/10/4908.pdf.

Lytle C. A., Fuller M. E., Gan Y. M., Peacock A., DeFlaun M. F., Onstott T. C., and White D. C. (2001) Utility of high performance liquid chromatography/electrospray /mass spectrometry of polar lipids in specifically $\mathrm{Per}-{ }^{13} \mathrm{C}$ labeled Gram-negative bacteria DA001 as a tracer for acceleration of bioremediation in the subsurface. Journal of Microbiological Methods 44: 271-281.

http://dx.doi.org/10.1016/S0167-7012(00)00245-1.

Mailloux B. J., Devlin S., Fuller M. E., Onstott T. C., DeFlaun M. F., Choi K.-H., GreenBlum M., Swift D. J. P., and McCarthy J. F. The role of aquifer heterogeneity on metal reduction in an Atlantic Coastal Plain aquifer. Geochimica et Cosmochimica Acta (Submitted).

Mailloux B. J., Devlin S., Fuller M. E., Onstott T. C., Sigman D., Williams K. H., Hubbard S. S., McCarthy J., and DeFlaun M. F. The fate of nitrate during stimulation of coastal plain sediments. Environmental Science \& Technology (In preparation).

Mailloux B. J., and Fuller M. E. (2003) Determination of in situ bacterial growth rates in aquifers and aquifer sediments. Applied and Environmental Microbiology 69: 37983808.

http://aem.asm.org/cgi/reprint/69/7/3798.pdf. 
Mailloux B. J., Fuller M. E., Onstott T. C., Hall J. A., Dong H., Beavis A. J., DeFlaun M. F., Streger S. H., Rothmel R. K., Green M. X., Swift D. J., Griffin T., Hubbard S. S., and Chen J. (2003) The role of physical heterogeneity on the field-scale transport and attachment of bacteria. Water Resources Research 39: 1142-1159.

doi:10.1029/2002WR001591, 2003.

Mailloux B. J., Fuller M. E., Rose G. F., Onstott T. C., DeFlaun M. F., Alvarez E., Hemingway C., Hallet R. B., Phelps T. J., and Griffin T. (2003) Design of a modular injector, multi-level sampler, and sampling manifold for groundwater tracer experiments. Ground Water 41: 816-827.

http://www.ngwa.org/publication/gw/toc03.htm\#6.

\section{$\underline{\text { Book Chapters }}$}

Fuller M. E. Use of the vital fluorescent stain CFDA/SE (5-(and-6-)carboxyfluorescein diacetate, succinimidyl ester) to label live bacterial cells. In Methods in Environmental Microbiology (F. Spencer, Ed.), Humana Press, (In press).

\section{Meeting Abstracts}

Fuller M. E. (2001) Laboratory and field studies examining bacterial transport and deposition in heterogeneous porous media (Invited Platform Session). ASM 101st Annual Meeting. Orlando, FL, USA.

Fuller M. E., DeFlaun M. F., and Onstott T. C. (1999) Development and evaluation of fluorescent labeling techniques for tracking bacteria injected into subsurface environments. ASM 99th Annual Meeting. Chicago, IL, USA. 
Fuller M. E., Dong H., Onstott T. C., and DeFlaun M. F. (1999) Development of new methods for monitoring bacterial transport in subsurface environments. The Fourth International Symposium on Subsurface Microbiology. Vail, CO, USA.

Fuller M. E., Streger S. H., DeFlaun M. F., Mailloux B. J., Hall J. A., Onstott T. C., Zhang P., and Johnson W. P. (2000) New vital fluorescent stain-based methods for in situ tracking of bacteria (Invited Platform Session). AGU Fall Meeting. San Francisco, CA, USA.

DeFlaun M. F., and Fuller M. E. (2002) Bacterial transport in heterogeneous porous media: Laboratory and field experiments. ASM 102nd Annual Meeting. Salt Lake City, UT, USA.

DeFlaun M. F., Streger S. H., Gillespie K. M., Dong H., Onstott T. C., and Fuller M. E. (1999) Investigation of bacterial transport by intact core experiments. ASM 99th Annual Meeting. Chicago, IL, USA.

DeFlaun M. F., Thomas, A., Colby, S. M., Butrym, E., Onstott, T. C. (1998) Using chemical reaction interface mass spectrometry (CRIMS) to monitor bacterial transport in in situ bioremediation. PITTCON'98. New Orleans, LA, USA.

Dong H., Monkman C., Scheibe T., Fuller M., and Johnson W. (2002) Direct determination of change of bacterial collision efficiency with transport distance in field scale bacterial transport experiments (Paper 42885). The Geological Society of America Annual Meeting. Denver, CO, USA.

Dong H., Onstott T. C., DeFlaun M. F., Fuller M. E., Gillespie K. M., Streger S. H., and Mailloux B. J. (1999) Mechanisms of bacterial retention in subsurface porous media revealed by phosphor and electron imaging. The Fourth International Symposium on Subsurface Microbiology. Vail, CO, USA. 
Dong H., Onstott T. C., DeFlaun M. F., Fuller M. E., Streger S., Gillespie K., and Fredrickson J. (1999) Bacterial transport in intact cores from Oyster, VA: A microscopic and radiographic study. AGU Fall Meeting. San Francisco, CA, USA.

Dong H., Onstott T. C., DeFlaun M. F., Fuller M. E., Streger S. H., Rothmel R. K., and Mailloux B. J. (2000) Transport of adhesion deficient bacteria in heterogeneous porous media: Relative dominance of physical vs. chemical control on bacterial transport. AGU Fall Meeting. San Francisco, CA, USA.

Hall J., Mailloux B. J., Onstott T. C., Fuller M., Streger S., Rothmel R. K., and DeFlaun M. (2000) The effect of physical and chemical sediment heterogeneity on aerobic and anaerobic bacterial transport. Goldschmidt 2000: An International Conference for Geochemistry. Oxford, U.K.

Johnson W., Zhang P., McIntosh W., Scheibe T., Onstott T. C., Fuller M., Dobbs F., DeFlaun M., Holben W., and Griffin T. (2002) Transport of bacterial probes in the subsurface: physicochemical and biological factors, or "Colloids wouldn't do that!" (Paper 43044). Annual Meeting Of The Geological Society of America. Denver, CO, USA.

Mailloux B., Devlin S., Onstott T. C., Sigman D., Hall J., Fuller M., DeFlaun M., Streger S., Williams K., Hubbard S., and McCarthy J. (2002) The fate of nitrate during an in situ biostimulation experiment. AGU Fall Meeting. San Francisco, CA, USA.

Mailloux B. J., Devlin S., Fuller M. E., Onstott T. C., DeFlaun M. F., Choi K. H., GreenBlum M., Swift D. J. P., and McCarthy J. (2003) The role of aquifer heterogeneity on metal reduction in an Atlantic coastal plain aquifer as determined by push-pull tests. AGU Fall Meeting. San Francisco, CA, USA. 
Mailloux B. J., Hall J., Fuller M., Scheibe T., DeFlaun M., and Onstott T. C. (2001) Transport mechanisms in silty, sandy media a inferred from short core experiments performed in the field. AGU Fall Meeting. San Francisco, CA, USA.

Mailloux B. J., Onstott T. C., Hall J. A., Fuller M. E., DeFlaun M. F., and Dong H. (2000) A methodology for scaling bacterial transport from the laboratory to the field. AGU Fall Meeting. San Francisco, CA, USA.

Mailloux B. J., Onstott T. C., Moline G., Dong H., DeFlaun M. F., Fuller M. E., Gillespie K. M., and Streger S. H. (1999) The determination of aqueous concentration profiles within intact sediment cores during transport experiments. The Fourth International Symposium on Subsurface Microbiology. Vail, CO, USA.

Scheibe T., Wood B., Ginn T., Johnson W., Zhang P., Onstott T. C., Hall J., Fuller M., and Dong H. (2002) Differential advection of colloidal and solute tracers in groundwater (Paper 43015). Annual Meeting Of The Geological Society of America. Denver, CO, USA.

Scheibe T. D., Ginn T. R., Fuller M. E., Onstott T. C., and DeFlaun M. F. (1999) Modeling bacterial transport based on laboratory experiments using intact cores. The Fourth International Symposium on Subsurface Microbiology. Vail, CO, USA. 